\title{
Tropical Island Imaginary
}

\author{
Stephen Torre
}

\author{
James Cook University
}

\begin{abstract}
This paper opens with a historical survey of the imaginary representation of islands in Western literature and then proceeds to a selective account of the island imaginary in largely 'middlebrow' writings and photography about the tropics. Complexities and paradoxes in the significances and semiotics of islands can be found in much writing about the Pacific islands of tropical Australia. E.J.Banfield largely established the paradisal perspective on tropical islands and extolled the lifestyle of the 'beachcomber'. The often challenged 'truth claim' that 'the camera cannot lie' is most pertinent to Hurley's work: what we see there is not only a speculum but more often a spectacle of the island imaginary; indeed the staging and replication of content so as to reflect what Hurley wanted to see in his subjects amounts to the substitution of a hyperreal, which then establishes itself in the discourse of the tropical island imaginary. Norman Lindsay tapped into some persistent motifs of the island imaginary: the excitement created by shipwreck and survival; the romance and salacious possibilities afforded by the attractions between a heroine and her suitors; and the realities of human nature stripped of civilised manners. Paradoxically, the popular works of Ion L. Idriess problematize the boundaries between material fact and textual discourse, tapping into what may well be a paradigm for the island imaginary in general-a space where contraries multiply and fantasies materialize. Lastly, Frank Clune's 'counterfeit adventures' similarly play around persistent binaries and stereotypes in the island imaginary, and perpetuate a reification of the complexity and elusiveness of their subject.
\end{abstract}

\section{Introduction: The Island Imaginary from Homer to Huxley.}

Tn accounts of the geography of the Earth emphasis usually falls on the great continents and their architectonics. Similarly, cultural, social, historical and political study overwhelmingly takes as its subjects the various countries and nation-states of those same continents. But just as the mode of science fiction posits an infinitude of other worlds beyond our planet, where things may be quite different (or uncannily similar), this same Earth harbours within it a vast number of alternative other worlds, whose stories are often more arcane. These island worlds can be located off the coast on continental shelves, or dotted throughout the oceans, but they are also found in large inland lakes, rivers, or coastal lagoons. These islands constitute a multitude - more than 180,000 islands are formally recognized by geographers. In terms of size islands range from tiny coral atolls no more than a few square metres wide to the 2.1 million square kilometres of Greenland, the largest terrestrial island. Some islands are uninhabited and barren; others, cornucopias and genetic breeding grounds of astounding biodiversity; still others are among the most densely populated areas on earth, such as the island of Manhattan. Islands provide us with a dazzling array of microcosmic versions of nature, culture and the interactions between the two. In some cases, islands are the sites of intense international political and economic struggle and change, in others, life continues on them as it has for centuries nurturing a harmonious and idyllic balance between human existence and natural environment.

Supplementing (in some cases displacing) the knowledge we have of the material facts of islands is a rich heritage of discursive material. An 'island imaginary', an archive of myths, writing, art, and song, has evolved from antiquity through to the present, which powerfully images unusual if not extraordinary encounters between self and place. Since the late $8^{\text {th }}$ 
century BC story of Odysseus' much interrupted and delayed decade-long sea journey back to his home in Ithaca after the Trojan War, islands have been a fascinating and complex presence in the imagination. Fundamentally formative in the island imaginary are the lands of the fierce one-eyed Cyclops, the carnivorous Lestrygonians, the bewitching Sirens, and the narcotic world of the lotus-eaters.

In the classical period The Romans saw islands as both holiday resorts and places of banishment remote from the culture and social world of the metropolis. They might also be abodes of the dead, or stepping stones to the afterworld. As trade and travel increased during the Middle Ages stories about exotic places proliferated. The Travels of Sir John Mandeville (approx 1371) — concocted from various secondary sources - delighted its readers with often outrageous stories of life and culture on islands. For example, on the Mediterranean island called "Crues" Mandeville tells us of men whose "ballocks hang down to their knees" (Mandeville Ch. 18) (now understood to be an example of the disease of elephantiasis which could affect any part of the body). Islands were not only the sites of extremes, but also shocking examples of the European other, where repression was thrown off. On the island of "Lamary" Mandeville disapprovingly relates how the tropical heat predisposes the population to go naked, which in turn encourages polygamy and promiscuity, which then promotes communal possession of partners and property, and lastly, cannibalism and the consumption of children (Ch 20). As we shall see, the notion that islands are inhabited by 'savages' is a persistent notion, evident in the semiotics of this cover from a 1994 coffee-table book on islands, which despite the vast diversity it describes, foregrounds a stereotypical picture of native in ceremonial dress, littoral, and palm trees.

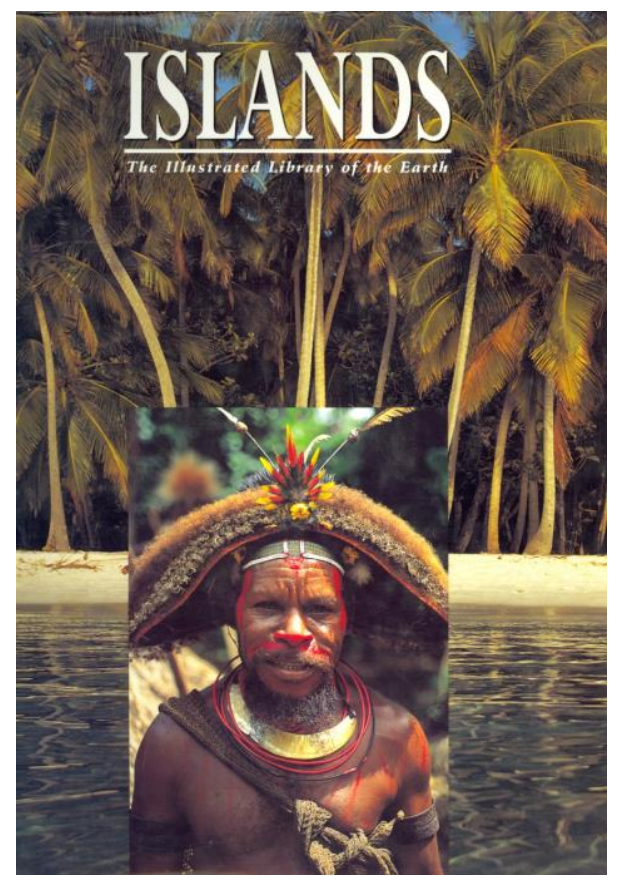

However, notwithstanding these persistent stereotypes, an enduring trope in the corpus of writing about islands is the contradictory ways in which they may be mapped in the imaginary. For example, in Shakespeare's The Tempest, first impressions of the island are not uniform: 


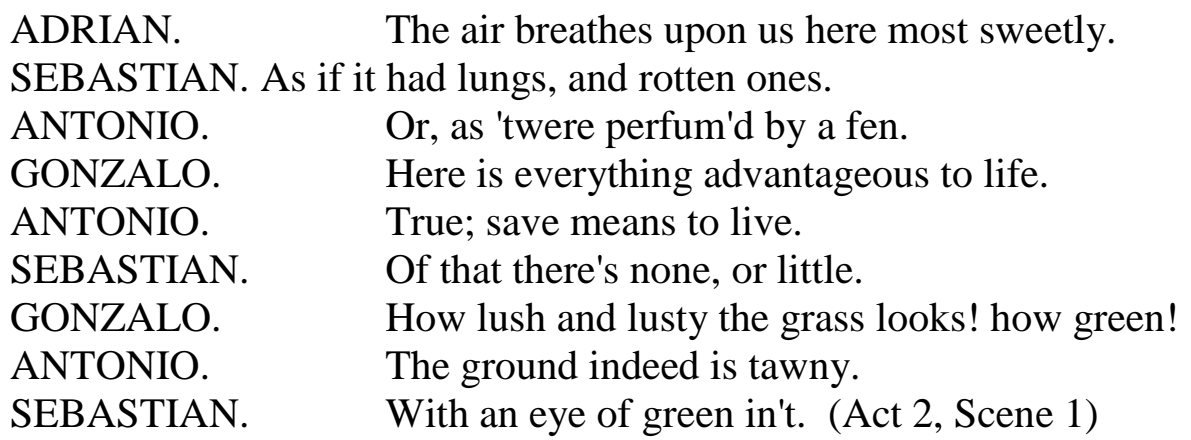

Indeed, this island has many faces: for Prospero it is the setting in which his 'magic' and power is nurtured; for the Neapolitan royals and their crew, it is the place of shipwreck and isolation; for Ferdinand and his father Alonso, it is the place of reconciliation and transformation; for Antonio, it is a place for continued machinations and assassination attempts; for Miranda and Ferdinand it is the scene of their romance and marriage; and for Ariel and Caliban, the island is the scene of their colonial subjugation, with Prospero gaining dominance over both spirit and matter.

Unlike Daniel Defoe in 1719, whose Robinson Crusoe tames Friday and the wild, and sets up a replica English civilization on his island, in telling the story of Gulliver's voyages between 1699 and 1715, Jonathan Swift faked the existence of numerous islands onto whose topography and inhabitants he projected every imaginable moral, political and intellectual folly and excess of Western civilization. These were grotesquely magnified in Brobdingnag, an island inhabited by giants, comically diminished in the minuscule people of Lilliput, and viciously satirized in the voyages to Laputa, Balnibarbi, Luggnagg, Glubbdubdrib, and Japan. The anodyne to Gulliver's Travels is The Coral Island: A Tale of the Pacific Ocean (1858) by Scottish author R. M. Ballantyne. The story relates the adventures of three boys marooned on a South Pacific island, the only survivors of a shipwreck. Among the novel's major imperialist themes are the civilising effect of Christianity, the spread of trade in the Pacific and the importance of hierarchy and leadership.

Although by the nineteenth century commercial shipping and other developments in communications had done much to de-mystify the facts about islands, they still formed the settings for diverse and fanciful subjects. In The Swiss Family Robinson (German: Der Schweizerische Robinson) (1812) Johann David Wyss, tells of a Swiss family shipwrecked in the East Indies while on its way to Australia. The story is intended as a moral and ethical guide and survival manual for young children, modelled on Defoe's character's values. In Herman Melville's Typee: A Peep at Polynesian Life (1846) the Typee way of life is favourably compared to European civilization (and its corrupting influence), despite the suspicion of cannibalism. Like The Swiss Family Robinson, Robert Louis Stevenson's Treasure Island (1883) is a coming-of-age quest story enlivened by a background of piracy.

Altogether grimmer are narratives where islands are the backdrop to human corruption and compromise. Marcus Clarke's For the Term of His Natural Life (1874) is a sensational novel about convict life on the island of Van Diemen's Land - a key work in the literature of islands as natural penitentiaries. Joseph Conrad's An Outcast of the Islands (1896) is the story of a man of compromised ethical standards who betrays the tribe who have given him protection. Adding an SF spin to the island setting we have H.G. Wells' The Island of Doctor Moreau (1896) about a sadistic doctor who uses vivisection to create monstrous beings to populate his beautiful island home; and Jules Verne's The Mysterious Island (1874) and The 
Lighthouse at the End of the World (1905), the former about strange events on a South Sea island eventually revealed to be the work of Captain Nemo, and the latter about piracy and survival in the South Atlantic.

In the twentieth century islands become the settings against which individuals maintain their socialization and dignity, or fall into primitiveness. For example, Henry De Vere Stacpoole's The Blue Lagoon (1908) is a romance about two shipwrecked children who, like Defoe's Robinson Crusoe, resist reverting to savagery, while William Golding's Lord of the Flies (1954) is a dystopian novel which inverts the morality of The Coral Island by depicting shipwrecked children's reversion to barbarity. Similarly, Golding's Pincher Martin: The Two Deaths of Christopher Martin (1956) is an existentialist novel which describes the descent into madness of a shipwrecked naval officer. Dystopian horror is evident in Franz Kafka's "In the Penal Colony" (1918), the classic story about an island penal colony in which a ghastly machine tattoos prisoners' sentences on their bodies until they bleed to death. In contrast, Island (1962)is Aldous Huxley's utopian counterpart to Brave New World, set on the fictional island of Pala where the life passage to transcendent being includes the use of drugs for enhanced awareness and self-understanding, managed reproduction, and communalism displacing the nuclear family.

\section{Tropical Islands}

While islands in the northern hemisphere and on the well-trafficked sea routes between Europe and the Americas lost much of their mystery by the late nineteenth and early twentieth centuries, tropical islands persisted as rather more exotic and unfamiliar places. In the tropics and the Pacific South Seas, head-hunters and cannibals populated the most exquisite (and sometimes infernal) islands in the popular stories of writers like Jack London, Robert Louis Stevensen, and Louis Becke. Their narratives moved uneasily between glowing accounts of the natural and often erotic lifestyles of island people, and overwrought sensational accounts of human abjection or barbarity, modulated by more covert subplots of colonialist expansion and cultural confrontation. The latter elements persisted in the scrutiny of expansionist powers seeking economic opportunity who acquisitively viewed islands as sources of commodity or labour treasure while uneasily contemplating their politically and socially elusive and unstable nature.

Such complexities and paradoxes in the significances and semiotics of islands can be found in writing about the Pacific islands of tropical Australia in the first half of the twentieth century. In his collection of stories, Little Known of These Waters (1945) R.S.Porteous presents islands and their surrounding reefs as potential scenes of shipwreck, around which mariners must chart a careful course. In bad weather their position is hard to fix, and they seem to move around like the ship-smashing Wandering Rocks of the Odyssey. Elsewhere in the work of Porteous, islands promise hidden treasure, the spoils of salvage, or protection from cyclones. They are also part of the maritime network of anchorages used for sanctuary or smuggling. Other writers for popular magazines, including Randolph Bedford, centred their narratives on the struggle for survival of the victims of shipwreck, presenting the contrary fates of Crusoe-like adaptation to the environment, or descent into despair and madness against a perceived hostility in nature. In contrast, William Hatfield's Barrier Reef Days (1948) (based on the author's holiday on Green Island) is a children's adventure story with many rich perspectives on nature and the indigenous cultures of tropical islands, revelled in by the children. Amongst the most popular and influential Australian voices contributing to 
the construction of the tropical island imaginary in the first half of the twentieth century have been E.J.Banfield, Frank Hurley, Norman Lindsay, Ion L. Idriess, and Frank Clune.

\section{E.J.Banfield's Island Paradise}

Journalist E.J.Banfield went to Dunk Island to recuperate from illness and set the tone for accounts of tropic islands as paradises in his several books including My Tropic Isle (1911) in which he said:

... this delicious Isle - this unkempt, unrestrained garden where the centuries gaze upon perpetual summer. Small it is, and of varied charms - set in the fountain of time-defying youth. Abundantly sprinkled with tepid rains, vivified by the glorious sun, its verdure tolerates no trace of age. No ill or sour vapours contaminate its breath. Bland and ever fresh breezes preserve its excellencies untarnished. It typifies all that is tranquil, quiet, easeful, dreamlike, for it is the, Isle of Dreams. (Banfield My Tropic Isle chap 2)

Banfield popularized the figure of the 'beachcomber', the island version of the flâneur. His commitment to island life though was certainly deep and empathic.

In Chapter Two of My Tropic Isle, “A Plain Man's Philosophy”, Banfield states:

Small must be the Isle of Dreams, so small that possession is possible. A choice passion is not to be squandered on that which, owing to exasperating bigness, can never be fully possessed.... Such is not for the epicure- the lover of the subtle fascination, the dainty moods, and pretty expressions of islands. The Isle must be small, too, because since it is yours it becomes a duty to exhaustively comprehend it.... Superficial intimacy with features betrayable to the senses of any undiscriminating beholder is naught. Casual knowledge of its botany and birds counts for little. (Banfield, My Tropic Isle Ch. 2)

My Tropic Isle drew together articles previously published in the North Queensland Register under the title "Rural "Homilies", and true to Banfield's aim provided readers with an immersive enclopeadic and empathic archive of island life - its history, topography, climate, flora and fauna, people and events:

All is lovable - from crescentric sandpit — coaxing and consenting to the virile moods of the sea, harmonious with wind-shaken casuarinas, tinkling with the cries of excitable tern-to the stolid grey walls and blocks of granite which have for unrecorded centuries shouldered off the white surges of the Pacific. The flounces of mangroves, the sparse, grassy epaulettes on the shoulders of the hills, the fragrant forest, the dim jungle, the piled up rocks, the caves where the rare swiftlet hatches out her young in gloom and silence in nests of gluten and moss-all are mine to gloat over. Among such scenes do I commune with the genius of the Isle, and saturate myself with that restful yet exhilarating principle which only the individual who has mastered the art of living the unartificial life perceives. When strained of body and seared of mind, did not the Isle, lovely in lonesomeness, perfumed, sweet in health, 
irresistible in mood, console and soothe as naught else could? (Banfield, My Tropic Isle Ch. 2)

Banfield was a fan of Thoreau and had found his own Walden Pond in the Great Barrier Reef about which he wrote prolifically for the Townsville Bulletin under the pseudonym 'Rob Krusoe'. After he had settled on Dunk Island Banfield was visited by a Cambridge graduate and naturalist, Sir Walter Strikland, whose interest in Buddhism also influenced Banfield's thinking. Banfield's own ideas resonated with the Buddhist notions of "the interrelatedness of all life and the sanctity of nature" and the idea that "human suffering and unhappiness are caused by the desire for material possessions"; also that "nothing is permanent and all existence is subject to continued change....that all life is interconnected spiritually and no single being has a unique, individual indemnity" (Bowen and Bowen 221).

These influences are clear in this passage from The Confessions of a Beachcomber (1908)

Whereas the average town-dweller could not endure the commonplaces of Nature which entertain me, rouse my wonder, enliven my imagination, and gratify my inmost thoughts, so his pursuits are to me devoid of purpose, insipid, dismally unsatisfactory. To one whose everyday admission (apology if you like) is that he is not as other men are - fond of society and of society's occupations, pastimes, refinements, and (pardon) illusions - the unsoiled jungle is more desirable than all the prim parks and clipped gardens; all this amplitude of time and space than the one "crowded hour." Here I came to my birthright a heritage of nothing save the most glorious of all possessions: freedom - freedom beyond the dreams of most men in its comprehensiveness and exactitude. (Banfield, The Confessions of a Beachcomber, last page)

Sadly, after her visit Jean Devanny wrote in 1944 "Those who revere the beachcomber and like clean and wholesome sea-borne things should keep away from Dunk" (29). Nevertheless, Banfield's work became and still is enormously popular, and while the islands he described may well now be mostly tourist resorts, he permanently implanted their paradisal nature in the tropical island imaginary.

\section{Frank Hurley's Photography: Truth Claim and Hyperreality}

The swiftly improving technology of photography and the advent of portable cameras such as the Box Brownie and the Leica 35mm camera in the early 1900s allowed for the proliferation of images which fed into the island imaginary-powerfully so, as they were read as authentic images of reality, part of the 'truth claim' of photography . A key influence here is the work of Frank Hurley who made many images of Papua New Guinea and the Torres Strait islands during two trips, the details of which are recounted in Pearls and Savages: Adventures in the Air, on Land and Sea in New Guinea (1924). Hurley's photos reinforce the binary suggested in the title between 'pearls and savages', or beauty and barbarity, or paradise and perditiona binary which is a persistent element in the island imaginary. He made many images of pearlers and the pearling industry, and of pearls themselves: 


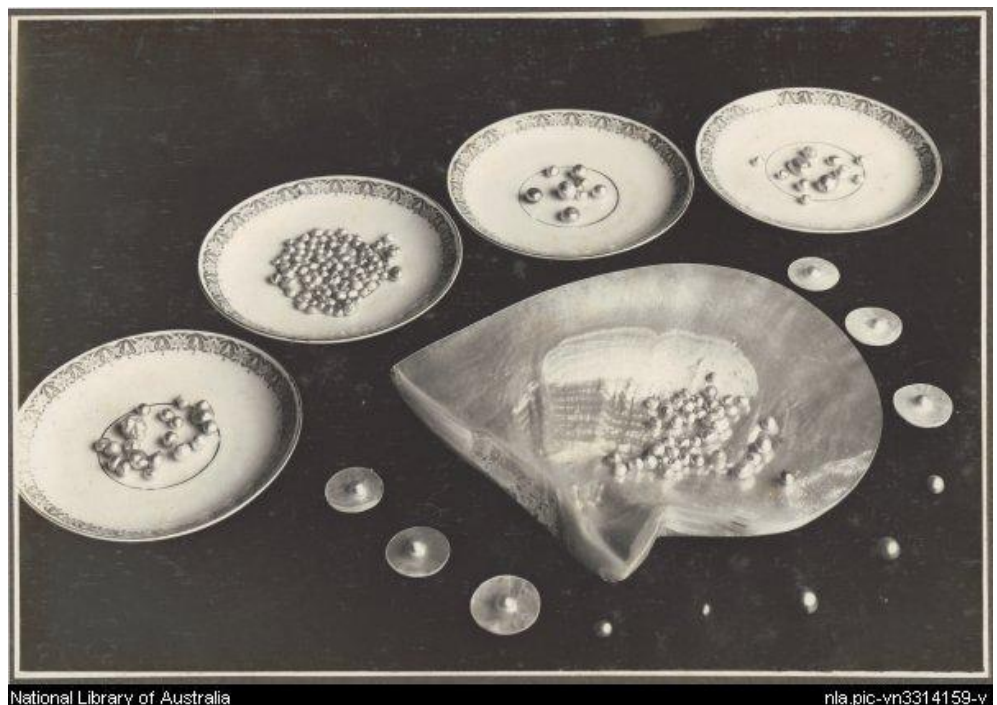

Hurley, Frank, 1885-1962. Pearls from Thursday Island.

1921. nla.pic-vn3314159.photograph: b\&w; 10.8 x $16 \mathrm{~cm}$.

His imagery of people created a clear boundary between the 'savage and the civilized'.

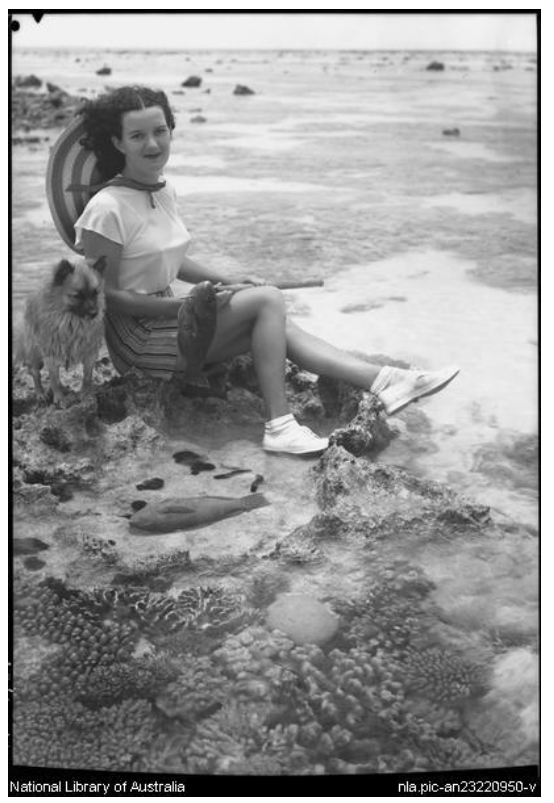

Hurley, Frank, 1885-1962.

Reefing, Heron Island.

[between 1910 and 1962]

nla.pic-an23220950. negative : acetate, $\mathrm{b} \& \mathrm{w} ; 16.2 \times 11.8 \mathrm{~cm}$.

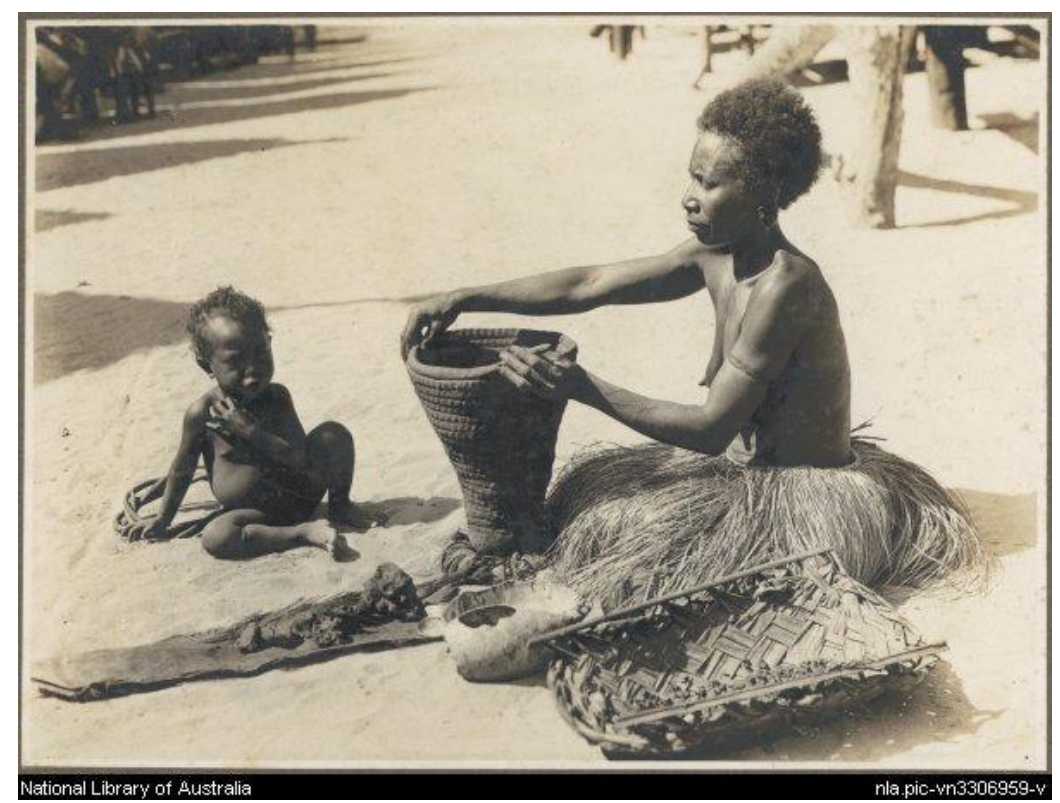

Hurley, Frank, 1885-1962.

Mailu Island types [woman and child seated on the sand with the woman handbuilding a clay pot] 1921.nla.picvn3306959 photograph : b\&w ; 11 x $15.8 \mathrm{~cm}$.

By all accounts Hurley was fascinated by the wild jungle environments of tropical islands and the equally exotic customs of the people who inhabited them. His stunning photographs of indigenous people in traditional dress, in their sacred sites, and enacting rituals and dance give a strong sense of opening a window into profoundly private and occult worlds. 


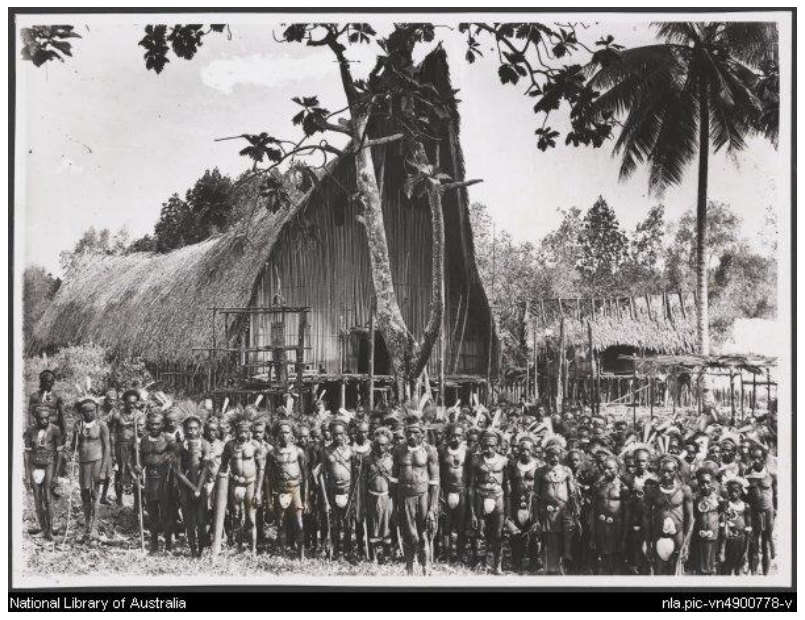

nla.pic-vn4900778

Hurley, Frank, 1885-1962.

Warriors standing outside the the great dubu daima of Urama, Papua New Guinea, 1921? [picture]

1921? 1 photograph : b\&w ; 19.3 x $24.8 \mathrm{~cm}$.

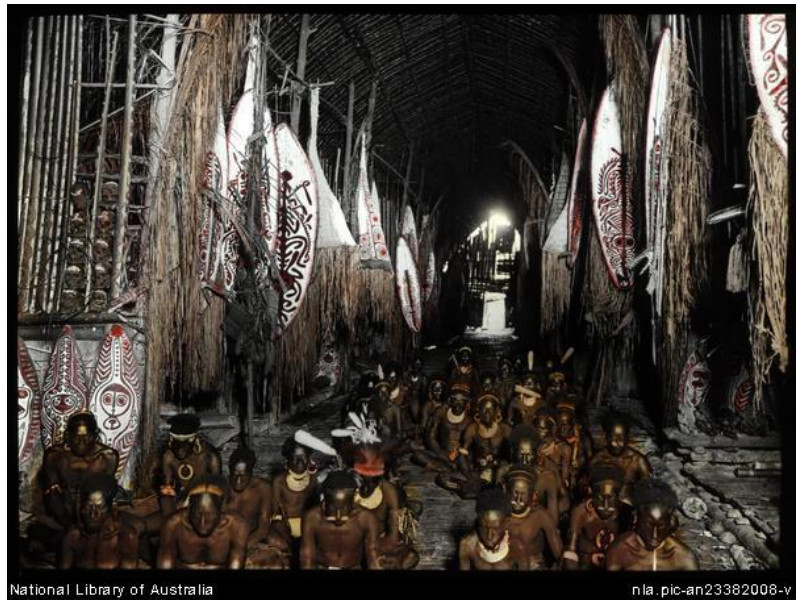

nla.pic-an23382008

Hurley, Frank, 1885-1962.

The interior of the Great Dubu Daima of Urama [picture] : [Papua]

[between 1910 and 1962] 1 slide : glass, lantern

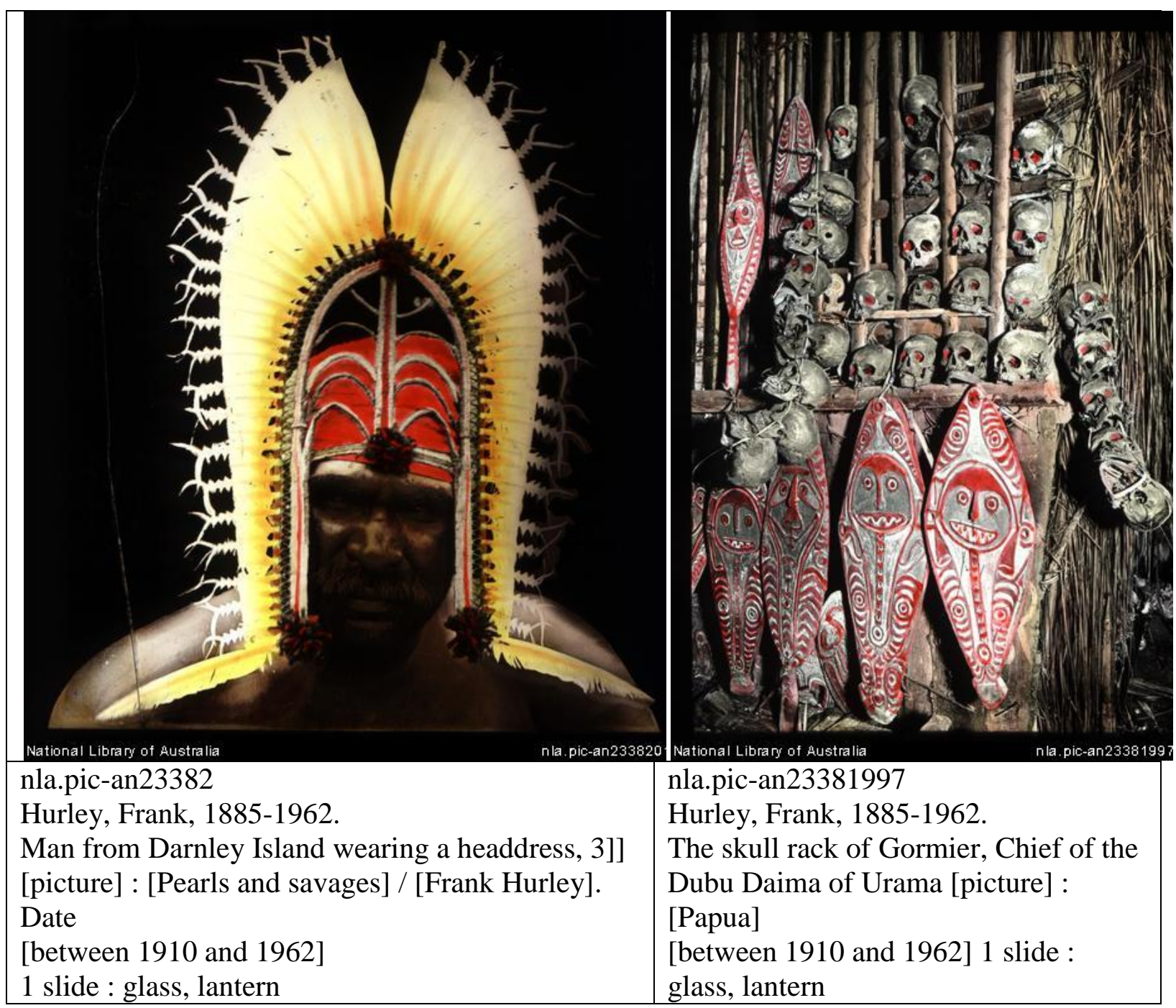



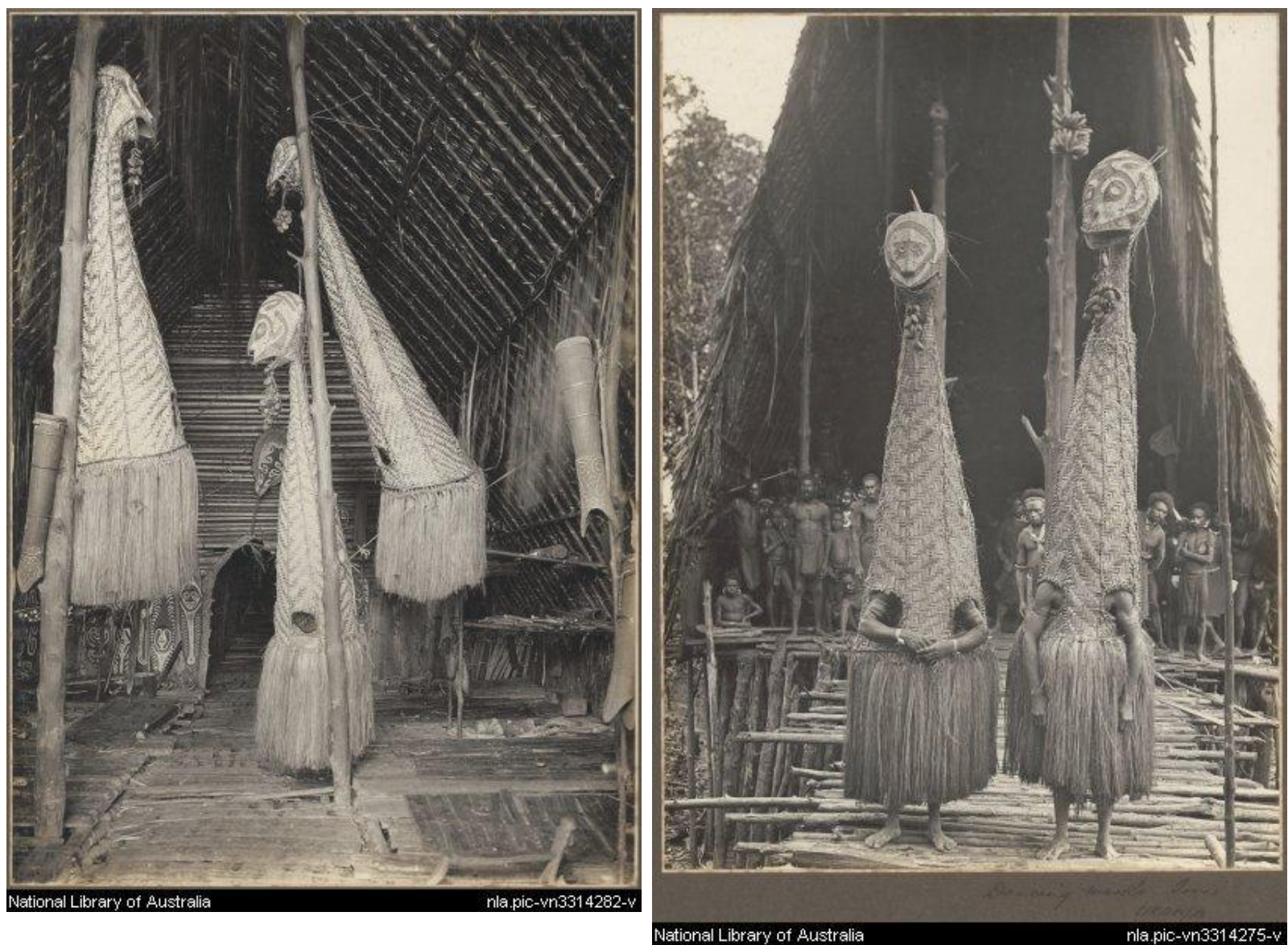

nla.pic-vn3314275

nla.pic-vn3314282

Hurley, Frank, 1885-1962.

Hurley, Frank, 1885-1962.

Dancing masks at Tovei, Urama [1] [picture]

Dancing masks at Tovei, Urama [2] [picture]

[1921]. 1 photograph : b\&w ; 34.3 x $24.6 \mathrm{~cm}$.

[1921] 1 photograph : b\&w ; 34 x $24.5 \mathrm{~cm}$. 


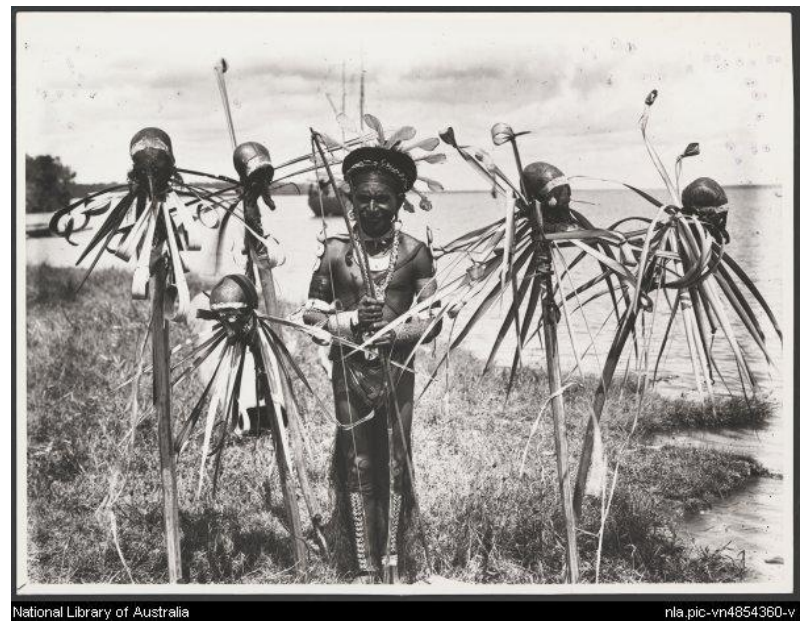

nla.pic-vn4854360

Hurley, Frank, 1885-1962.

Village head man standing with skulls impaled on posts facing the river as a sign of hospitality, Kerewa village, Goaribari Island, Papua New Guinea, December 1922 [picture] 1922. 1 photograph : b\&w ; $15.7 \times 21.1 \mathrm{~cm}$.

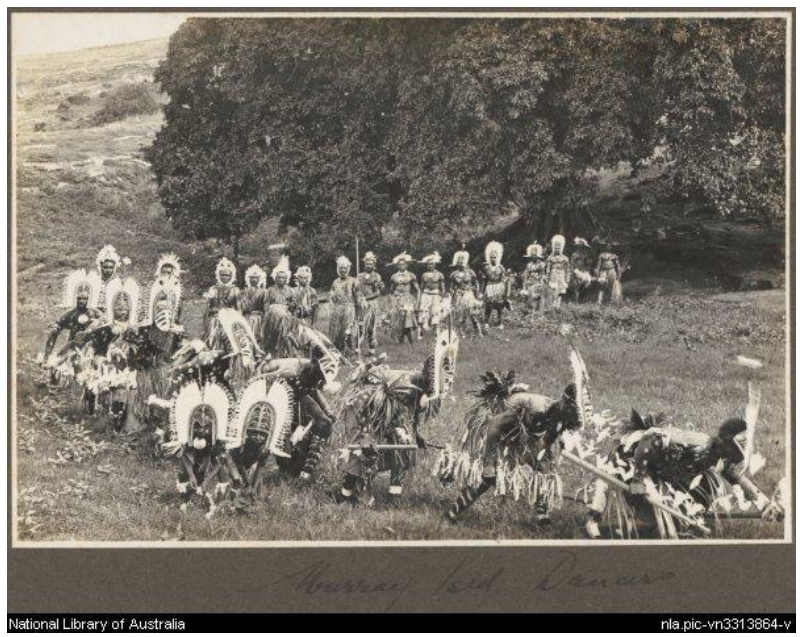

nla.pic-an10668912-27

Hurley, Frank, 1885-1962.

Pantomime dancers - Murray Island [picture] [192-?] 1 photograph : silver gelatin, sepia ; $12 \times 16.5 \mathrm{~cm}$. or smaller.

In his authoritative biography, Frank Hurley: A Photographer's Life (2004), Alasdair McGregor draws extensively on Hurley's letters and writings showing that Hurley's attitude to his subjects was ambivalent. On the one hand he had "great admiration for these outpost missionaries who dwell in the heart of a wild uncouth people, trying to turn them from heathen worship, administering to their ills and doing the good they can" (quoted in McGregor 223) while at other times he deplored the cultural interference that explorers and missionaries caused in native communities: "how bizarre and unaesthetic" he opined "the flowing mother-hubbards of the women! How absurd the names of the men, Matthew, Mark, Luke and John prefixed to such names as Nuwred, Gogotin and Tagiriger!" (quoted in McGregor 227). Similarly, Hurley sometime shows admiration for the natives, as in this description of dancers: "Arrayed in warpaint, bedecked with a burden of ornaments and crowned with a garnish of feathers the actors were indeed a brilliant and gaudy assemblage... one fell in admiration contemplating the accumulation of feathers (quoted in McGregor 233). At other times the camera sees not the spectacle and we get: "The dancing was a succession of hopping, wriggling, stamping, jumping, bending, swerving, sweating - glorified physical jerks without grace but all performed in perfect rhythm" (quoted in McGregor 226). It seems Hurley believed that Western contact would eventually improve the lives of the natives, an inevitable and positive development despite its cost in cultural terms. But his photographic eye wanted to see islanders in their authenticity - the more savage the better. He obsessively photographed the secret recesses of men's long houses or daima on Urama Island, observing "the darkness [of the interior] and fantastic things that encumber these dubus impress upon one a gloomy awe and ...forebodings of evil...these people only a few years back were ardent cannibals" (quoted in McGregor 232). And indeed his many photographs of natives surrounded by their trophies of skulls seem to provide incontrovertible metonymic evidence of their past activities.

As well as touring slide-show exhibitions of his photographs of the tropics Hurley made a film entitled Pearls and Savages in 1921. Clips are online here: http://aso.gov.au/titles/documentaries/pearls-and-savages/clip1/?nojs 
A selection of his most exotic and diverting images with other multimedia elements, the work was, according to Liz McNiven of the Australian Film and Sound Archive, pioneering:

[Hurley's] interest lay in the commercial image rather than the production of an ethnographic record: he used the camera to create art rather than to document actuality. In fact, Hurley helped establish the adventure film genre, with a format replicated by many adventure travel programs today. He went to great lengths to get exciting footage... One intertitle refers to 'citadels of headhunters' then shows Hurley's party walking across grassland carrying rifles, as spears fly between them and the camera. It would seem this obviously staged scene aimed to create drama for this 'headhunter' sequence....Blurring the line between fiction and non-fiction became a hallmark of Hurley's work, triggering ongoing debate about its authenticity. He never let the truth get in the way of his story. http://aso.gov.au/titles/documentaries/pearls-and-savages/notes/

McNiven also notes that over 800 artifacts were 'dubiously obtained' by Hurley and his associates, leading the Papuan administrators to ban further trips by Hurley to Papua.

Although this is a "beautiful film on face value" concludes McNiven "the issues surrounding its making, namely the representation, cultural appropriation, and repatriation of cultural materials, remain as pertinent today as when Hurley produced this footage in the 1920s"

The often challenged 'truth claim' that 'the camera cannot lie' is most pertinent to Hurley's work; what we see there is not always a speculum but more often a spectacle of the island imaginary; indeed the staging and replication of content so as to reflect what Hurley wanted to see in his subjects amounts to a Baudrillardian reduplication of the real, the substitution of a hyperreal, which also finds its welcome home in the tropical island imaginary.

\section{Norman Lindsay: Desert Islands and Desire}

Norman Lindsay, the writer of Australia's best known children's story, The Magic Pudding, first attracted attention for his Bacchanalian paintings on classical themes which were a somewhat hyperbolic version of his bohemian philosophical positions on art and creativity. Lindsay's advocacy of freedom of expression, natural and artistic beauty and passion, of Nietzschian vitality and virility, were focused through a theory of 'creative effort' which empowered the artist to rise above the mundanity of ordinary life to the vision of Platonic transcendent reality. For many, his images and writings were at best smut, at worst blasphemous. Among works that were at various stages censored and banned are included two novels, The Cautious Amorist (1932) which was banned in Australia from 1934 to 1958, but made into a film in Britain as Our Girl Friday (1953); and Age of Consent (1938), also filmed in 1969 though substantially censored prior to being restored and re-released in 2005. 

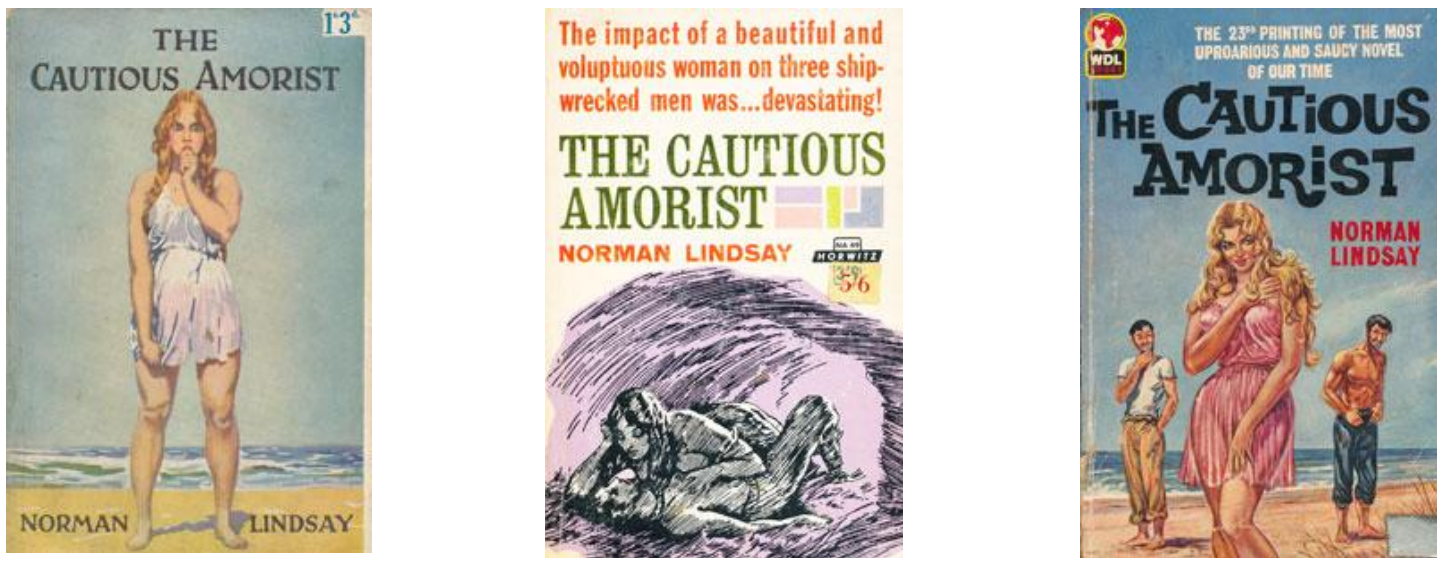

Lindsay's story concerns the shipwreck of three men and a woman. The location ("three days out from Honolulu" (2)) suggests an island in Polynesia. Lindsay was well aware of the metaphoric associations of islands, and had painted a siren scene.

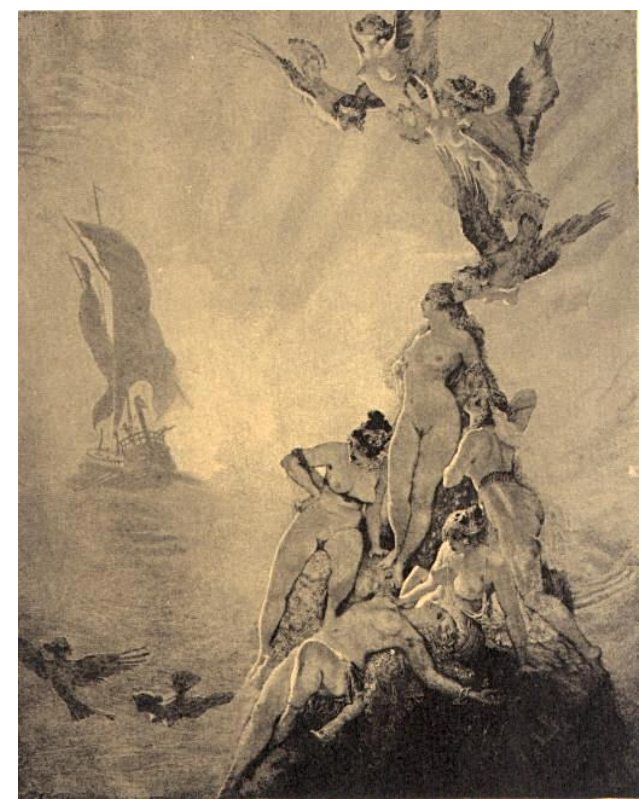

Desire indeed seems to be at the centre of The Cautious Amorist, with its three male characters-James Carrol, a cynical journalist, Patrick Plunket, an amorous and virile stoker, and the Rev. Fletcher Gibble - circling around the beautiful Sadie Patch. At first the characters must cope with basic survival, and Lindsay uses their conversations to satirize conservative social mores and behaviour. But soon more primitive human emotions come into play, and brute survival and sexual competition divide the men, and complicate Sadie's life as she grows in independence while having to deal with the discord created by her amours with each of them. As the 1969 Horwitz paperback blurb put it:

A beautiful, voluptuous girl. A cynical journalist. An amorous, virile stoker. A shy, bewildered clergyman. Shipwrecked on a desert island, they face a primitive new life together. And as each of the men becomes increasingly aware of Sadie's obvious charms, an impossible situation becomes an uproarious comedy. (Lindsay, The Cautious Amorist, 1969, back cover) 
Lindsay's sketches in themselves narrate a cycle in which the characters are progressively stripped of their clothes and the trappings of civilization, confront their instinctual needs for survival and sex, and then return to their usual social mores after rescue. In a shallow Lawrentian analogy, those in whom desire is repressed are imaged as thin and sickly, while the locus of libido itself, Sadie, grows in voluptuousness and radiance, and her lovers also seem to develop body-builder physiques.

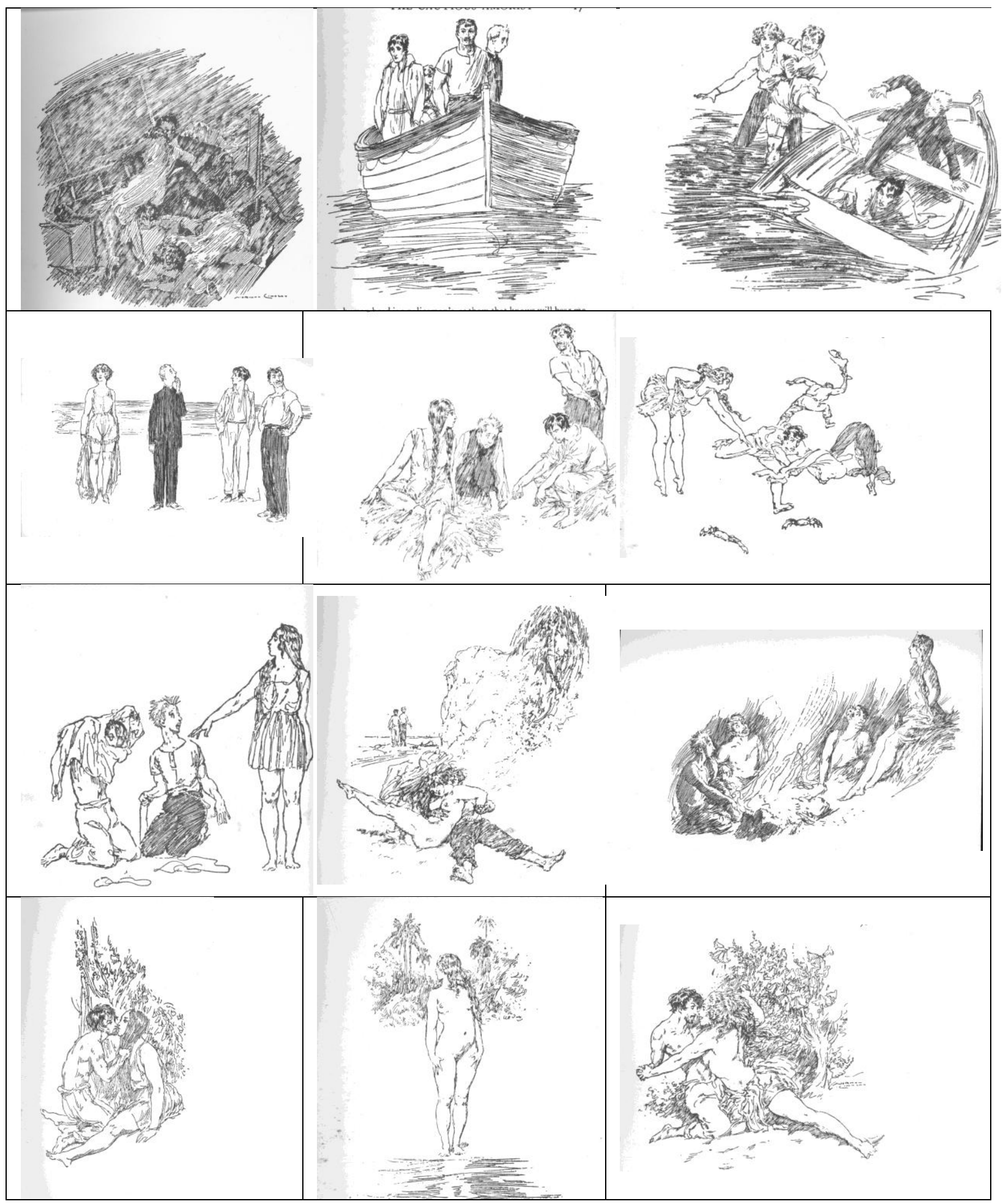


etropic 12.2 (2013): Tropics of the Imagination 2013 Proceedings | 259
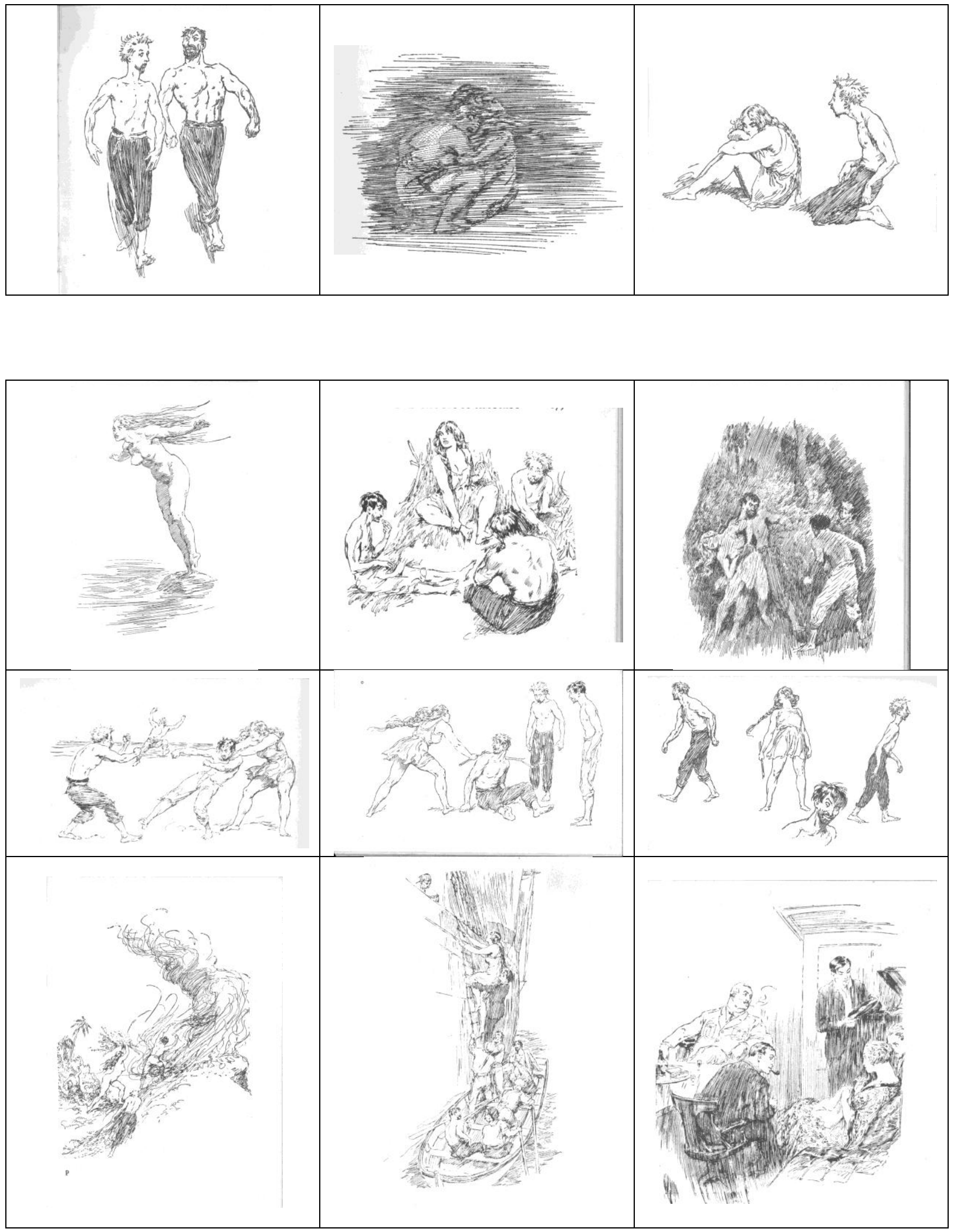


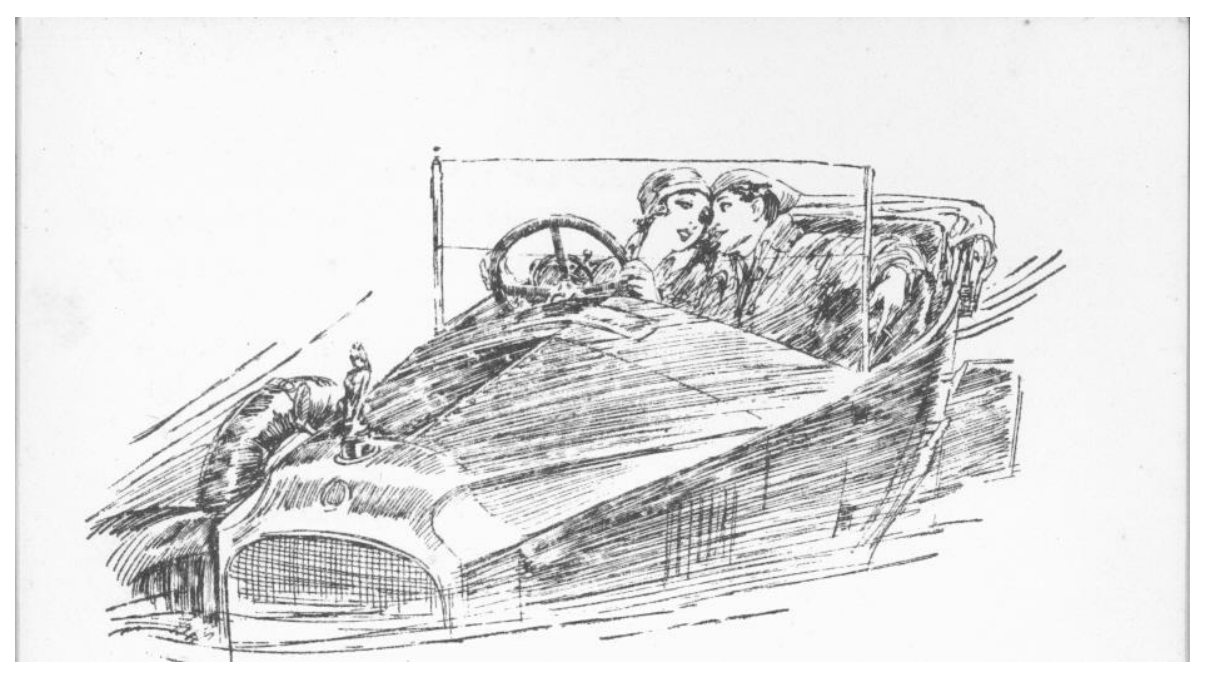

Despite the somewhat lightweight nature of its themes, and the absence of any discussion of the island itself, there is no doubt that Lindsay tapped into some persistent motifs of the island imaginary: the excitement created by shipwreck and survival; the romance and salacious possibilities afforded by the attractions between the heroine and her suitors ( a persistent element of island life since Fletcher Christian discovered the delights of Tahiti) ; and the realities of human nature stripped of civilised manners.

The movie of Age of Consent (http://www.youtube.com/watch?v=UHrEmY2RqyU) is now seen as a formative and pioneering piece in Australian cinema history-however although Australians were involved in the production and bit parts, it was the last film of British director Michael Powell and starred James Mason and Helen Mirren. A major appeal of the movie came from being filmed on Dunk Island in the Great Barrier Reef although Lindsay's vaguely autobiographical novel about a painter who heads off to seclusion to renew his artistic inspiration was in fact set on an isolated lagoon on the coast of New South Wales. But both versions certainly capitalize on elements of island imaginary for their appeal.

Bradley Mudgett finds inspiration for his art in the beauty of his natural surroundings; but increasingly his paintings begin to foreground his model, Cora, a wild orphan child of the island, who undergoes a transformation from innocent child of nature to the eroticized subject imaged in the poses Bradley asks her to assume for his paintings. The realization of creativity concomitant with the fulfilment of desire are the endpoints of this typical island plot. But two sub-plots of a murkier nature also reinforce Lindsay's pervasive themes of the transforming value of beauty, passion and sexual self-expression versus the destructive consequences of sexual repression, conservatism and materialism.

Cora's inept guardian is her grandmother, Old Mother Spadgett, a gin-guzzling crone whose witch-like appearance establishes her 'enchanted island' pedigree. She is particularly condemnatory of Cora's emerging sexuality and also determined to keep Cora in subjection, since Cora collects the fish and lobsters which are sold to keep her grandmother supplied with gin. Cora has secretly been taking a cut so she can save enough to get away from the island, but Ma Spadgett finds the money, and after an altercation she dies. This frees Cora from her wicked grandmother's spell, and she goes to the shelter of Bradley with whom she cohabits happily ever after.

The other sub-plot also concerns sexual repression. Also an inhabitant on the island is a spinster Miss Marley, living in a time-capsuled colonial residence with her dog. One day, 
Podson, who is visiting Bradly while on the run from alimony payments, spies Miss Marley strolling along the beach while he is skinny-dipping. When Bradley's dog Edmund attempts carnal knowledge of Miss Marley's dog Jasper Podson instinctively intervenes to separate the dogs, but his nakedness elicits a hysterical reaction from Miss Marley. Sometime later he calls to make his apologies and is invited to dinner. The lavish dinner proceeds well, with Podson entertaining Miss Marley with his usual lies and exaggerations, as well as stories of his womanizing. The climax of the scene occurs when Miss Marley, reserve and repression having reached breaking point, throws herself on Podson in a violent sexual embrace. Podson is last seen fleeing for his life.

Again, Lindsay's etchings are a nice complement to the story.

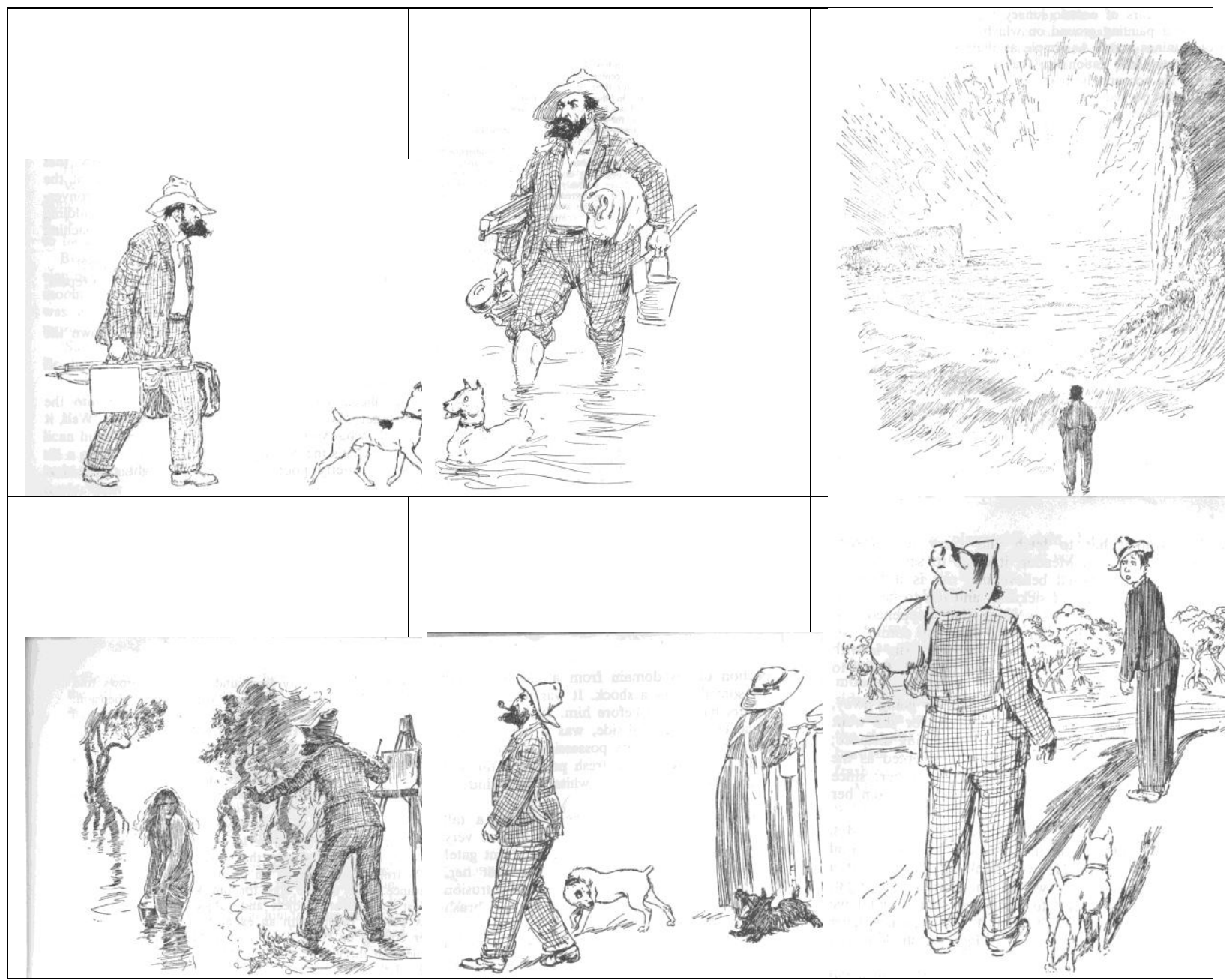



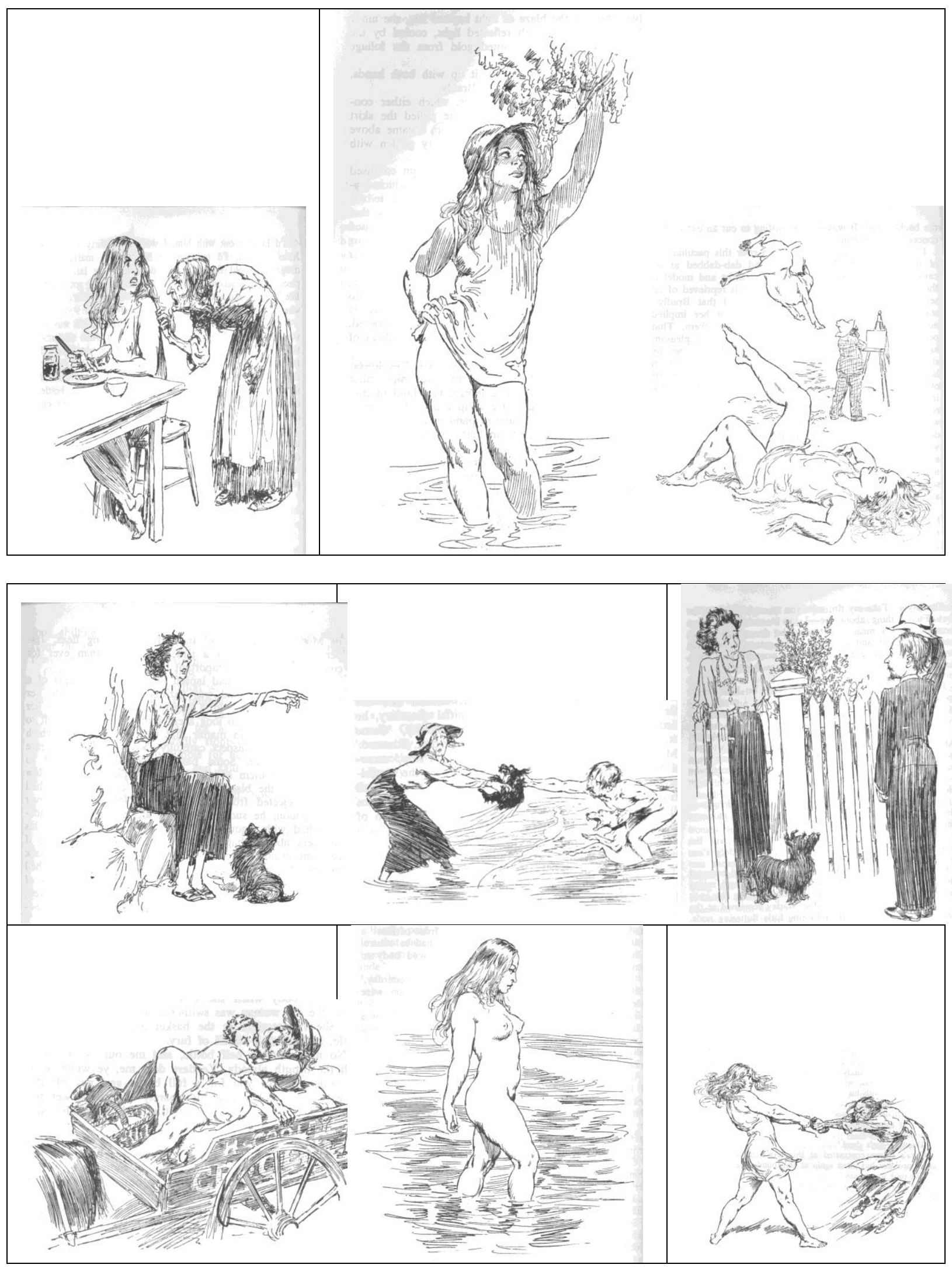


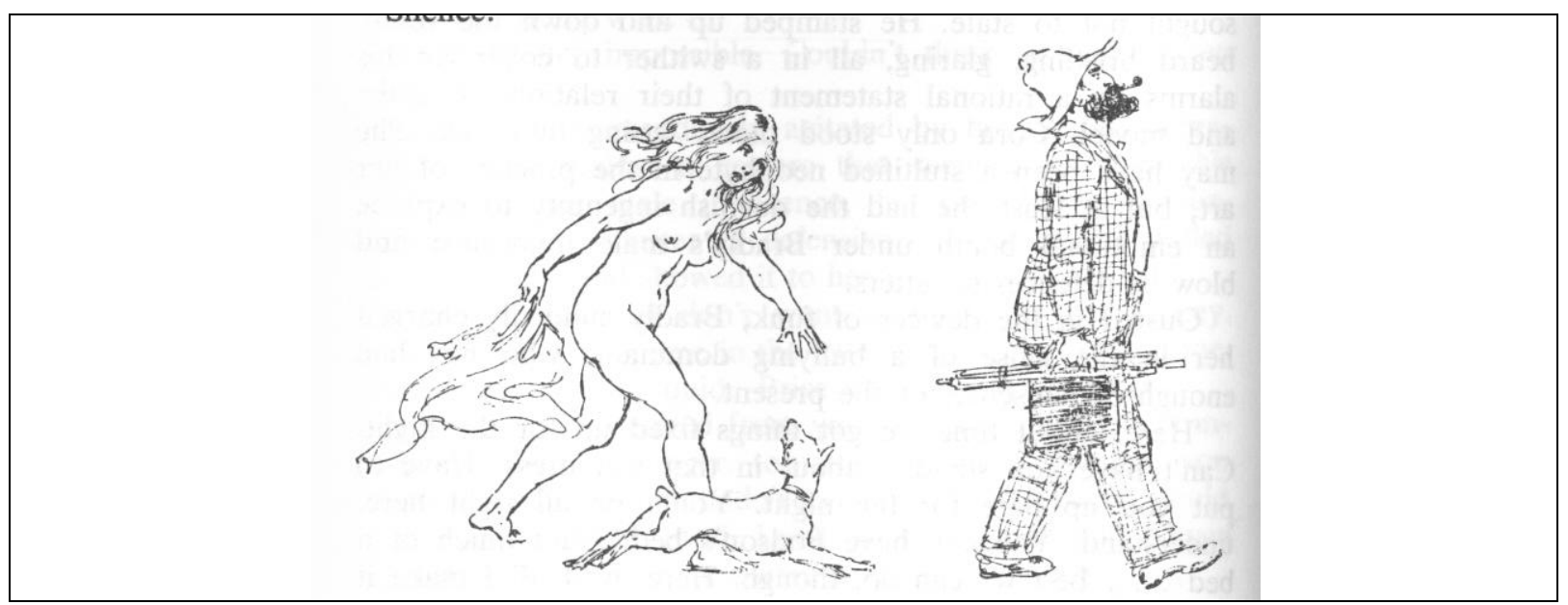

\section{Ion L. Idriess: Fiction into Fact}

Ion Idriess was a prolific author who wrote for popular Sydney magazines (the Bulletin and the Sunday Pictorial for example) and published a book each year between 1931 and 1964. His many occupations carried out in the Australian tropics, the Torres Strait, Papua New Guinea, the Great Barrier Reef, and the Middle East, included working as a pearl diver, a station hand, a rabbit-exterminator, a crocodile and buffalo hunter, a gold-fossicker, a surveyor, and a member of the Australian Light Horse. Although he wrote several novels, most of his work is in the feature-story mode, with some imaginative recreation of setting, character and dialogue (as we find in the work of his contemporary, Frank Clune). Beverley Eley in her biography of Idriess notes that Thursday Island and Murray Island (known as Mer to its natives) "were islands of pure joy for Jack....The people were a happy-go-lucky lot with plenty of time. Their philosophy of 'think about it tomorrow' was one which Jack found easy to adopt" (Eley 112). Similarly Idriess' contemporary, Dr Younge, who published $A$ Year on the Great Barrier Reef in 1930 had written: "The beauty and luxuriant vegetation of Mer cannot be portrayed in words. Only Samoa can be compared to it, and the climate of Murray Island is infinitely superior to the oppressive steamy heat of Samoa" (Quoted in Eley 115). Yet Idriess had also come under the spell of stories he had heard about mysterious and barbaric customs, about the fates of shipwreck survivors, and about dramatic adventures.

Says Eley: "While Younge was awed by the obvious, Jack was steeped in the lusty brutality of a civilization which had for centuries fed on the rituals of death which were paralleled by the vigorous jungle growth which fed on decay while reaching for the sun" (Eley 115).

Out of such experience came Drums of Mer (1933), an 'exotic novel of black magic, passion and survival' as the cover shouts. 


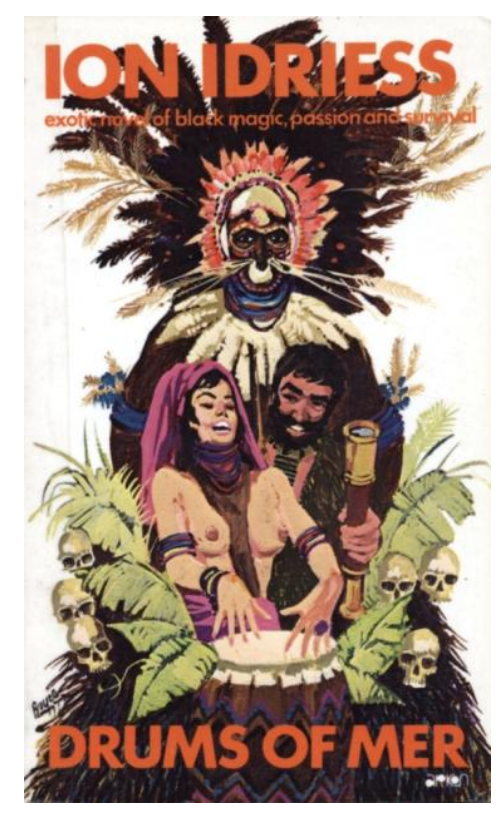

The reception history of this work is enlightening to say the least. It was popular enough to be reprinted several times, and there were several (ultimately all unsuccessful) attempts to make a film version of it. Interestingly the book was regarded by the Murray Islanders as a sacred history of Mer, as the secret sites and rituals Idriess described would otherwise have been lost forever. Idriess was ordered by his publishers to remove any mention of 'flying men with supernatural powers' from the book, even though these beliefs were an integral part of Murray Islanders' culture (Eley 154).

A contemporary review in a 1933 edition of The Queenslander gives a good synopsis of the work.

[Drums of Mer] tells of the life of the original inhabitants of the islands of Torres Strait before the white pearlers had established themselves there. The Island of Mer (now known as Murray) was the head centre, as it was the home of the principal Zogo-le.... He had a mystic capacity for knowing what was happening beyond sight, and "but a thought from him could bring death" to the multitude. He was "supreme arbiter in life, and - they believed — after death, of the destiny of many people.

...There were traces of Spanish descent to be found in the natives of Mer. These Spaniards, as well as all other white people, were known to the islanders as "Lamar" or spirit people, and were believed to be the reincarnation of natives who had died. With this material and an Australian boy who had been shipwrecked on Mer when 16 years of age and had been adopted by the inhabitants, and a white girl who had been saved from another wreck in infancy...the author has woven a most romantic tale of island love and hate, and voyaging and fighting. He literally revels in gore-not because Mr. Idriess himself is bloodthirsty, but because, as he somewhat plaintively explains in a preliminary note, the fights and massacres, mysticism, and cruelty were once part of the life of these people. Ethnologically, he claims, the story is correct. $\mathrm{He}$ had the benefit of the reports of the Cambridge Anthropological Expedition to Torres Strait, and of consultation with "that living mine of Torres Strait ethnological lore, the Rev. W. H. MacFarlane (the well-known 'Wandering Missionary of the Strait'".... The author has perhaps exaggerated the romantic element, but there was really little need for exaggeration - the legends themselves were romantic enough." ....It is fortunate that the opportunity offered itself to Mr. Idriess to record these stories in a 
book, for the old men who know them are fast passing away, and in a few years they would have been lost in the mists of the past. [The author's] lapses in [authenticity] need not be regarded as serious [as] indicated by the dictum of the writer of the foreword, that "the author has travelled the Strait with the discerning eye and contemplative soul of the artist who is satisfied only with first-hand colour, and who, while blending history and romance with subtle skill, at the same time keeps within the region of fact." What better imprimatur could an author desire for a book? (“'Drums of Mer.' : A Story of the Strait." 44)

This review was typical of the popular reception, with its delight in a work that while insisting on being true, provided fantastical stories, horror, and romance in an island setting - a good reason for suspending disbelief at the expense of "the region of fact". Later, much of this frontier literature came under renewed critical scrutiny by postcolonial critics, who presented somewhat more negative responses, deconstructing complex imperialist and colonialist ideologies in the works. Typical of this was Robert Dixon's "Captives and Inmates: Ion L. Idriess' Torres Strait Trilogy and the Aborigines' Protection Act" and Barbara Creed and Jeanette Hoorn's Body Trade: Captivity, Cannibalism and Colonialism in the Pacific.

But, as we have noted, it wasn't just white readers who found Drums of Mer appealing. People of the Torres Strait also found in this work something which spoke to them. Maureen Fuary's rethinking of the impact of the work on island culture is interesting. She states that Drums of Mer:

...constitutes an important document through which many Torres Strait Islander people, especially men, have come to know themselves, white others, and their past. Unlike literature-based deconstructions of Idriess and in particular those critiquing his representations of Aboriginal and Torres Strait Islander people...my paper argues that in seriously attending to Torres Strait readings of Drums of Mer we can see that for contemporary Torres Strait readers, it is not themselves who are other but rather the white protagonists (Fuary 248-49).

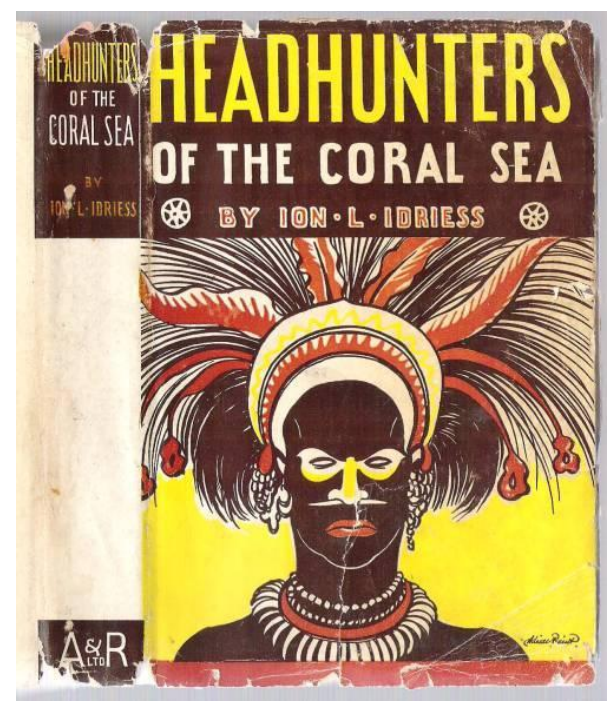




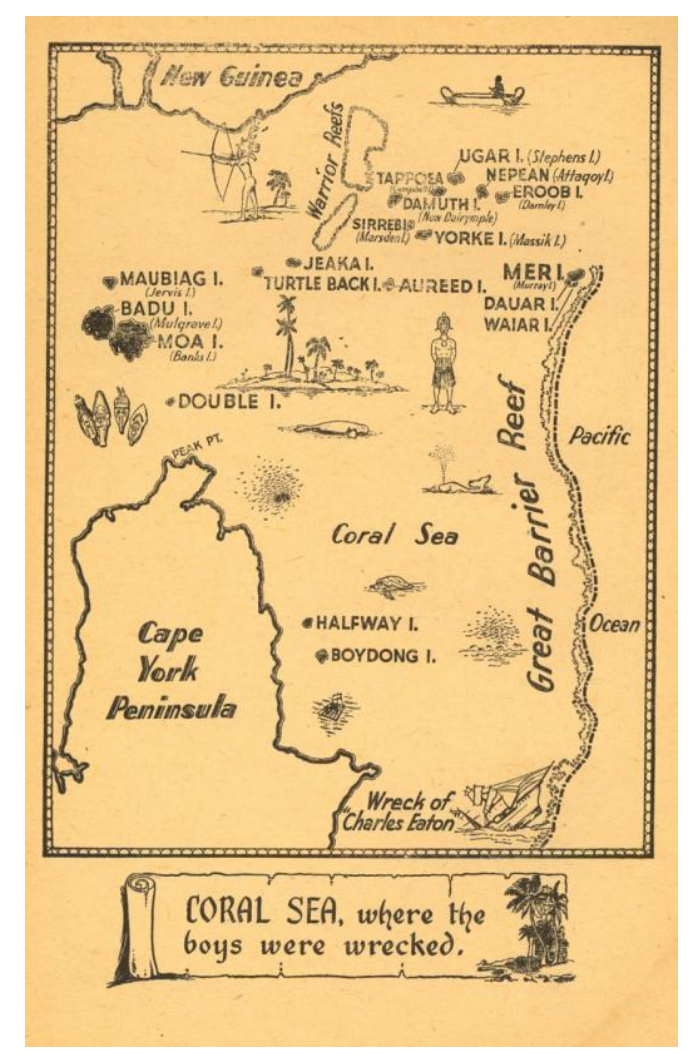

Nonetheless, the ambivalence of Idriess' texts is evident throughout his oeuvre. Even in a novel he wrote for 'juvenile' readers, Headhunters of the Coral Sea (1946), based on a true story of two boys, Jack Ireland and Will D'Oyly, who were shipwrecked and brought up by the islanders as 'Lamars', we find this hesitation between affection for the islanders, yet wariness of their potential savagery. This is after all a captivity narrative and in the end the boys are "rescued from the savages" (vii). But although we are treated to gruesome tales of fierce battles with spears and clubs and threats of decapitations, when the boys are about to be removed their native guardians are moved to lamentations.

A split in identity is evident in the boy 'lamars' too-when they board the boat that will return them to civilization they feel like they are between two worlds:

Unhappily Jack realized that these men [the crew of the Isabella] could only partly understand him; he had heard the crew whisper that he was "native", that he was nearly a half-with after his life among the savages. He spoke in English with many words of Mer; he had already given up trying to explain to these men numerous customs of the islanders which he understood so well. He now realized they would never understand. They called him a half-wit-he who was a warrior of Mer, and he wondered what sort of a life lay ahead of him, when once he reached civilization again. (218)

The topography of the island itself reflects this split: it encompasses all the feature of tropical lushness, verdant jungle and a littoral of dazzling and contrasting colour - but also the forbidden valley, "a dreadful valley, lifeless and forlorn; not a bush grows upon it, not a bird whistles there. It was believed to be the abode of the dead before they depart to the Blessed Isle of Boigu, far up in the heavens" (67). 
These splits are subsumed by the pliability of fact and fiction in Idriess' island stories which is nowhere more evident than in the publication history of Madman's Island. In 1922 Idriess met a prospector, Charlie, with whom he travelled to Number One Howick island, having heard from a Malay that tin and wolfram were to be found there. A schooner dropped them off, but failing to pick them up on its return journey the pair were effectively marooned for seven months. It then emerged that Charlie had a serious medical condition (bizarre in the extreme) and having run out of medication soon descended into madness and made several attempts on the life of his mate. When Idriess finally was rescued he was mentally and physically frail. After recuperating, Idriess had a conversation with Alec Chisholm, the editor of the Daily Telegraph. According to Idriess' 'Author's Note' this is what transpired:

"You ought to write a book," [Chisholm] declared.

I laughed derisively. "Not in my line. The nearest I've ever got to that is an old diary I kept on an island."

He grabbed his hat with one hand, my arm with the other.

"Come on!" he commanded.

Straight across Castlereagh Street we went, into the publishing house of Angus and Robertson Limited, and upstairs to a desk at which stood a tall man with a black beard, smiling face, and kindly eyes.

Chisholm introduced me, adding: "He has a book you must publish."

"Must I?"

"Yes, It's a good one. Tropic isles and brown sea-maids and oceans of romance.

In alarm I hurriedly explained that the "book" was merely a rough diary written on an old sea log to save myself from going mad. There was nothing of interest in it at all —only two men on a barren island.

The big man with the black beard looked mildly interested. "Bring it along and we'll read it" he suggested.

And so it all started....

"Start from where this opium came ashore," decided Mr Robertson. Be rescued as you tell here, but from there on have adventures with the opium and bring in a love interest quickly. Any beautiful girl will do. Marry her and I'll take the responsibility."

Somewhat in a daze, I was given to understand that if I altered the end of the diary and wrote the whole as a continuous narrative with a love interest, he would publish it.

Quite startled at the idea of writing a book, but becoming interested, I set about the job - in a very amateurish way. The book was published - and failed.

Now (years later) the publishers have prevailed upon me to rewrite Madman's Island, strictly according to fact, eliminating the fictitious love interest. Hence the present Madman's Island. (Madman's Island v-vii)

\section{Caveat lector!}

This primal scene probably applies to more than just the problematic boundaries between material fact and textual discourse in the writing of Ion L Idriess; it may well be a paradigm for the island imaginary in general - a space where contraries multiply and fantasies materialize. 


\section{Frank Clune: Counterfeit Adventures}

Until 1923, when he re-married at the age of 30, Frank Clune travelled extensively overseas and in Australia, including service at Gallipoli. Some of his more colourful occupations included a vaudeville performer and mousetrap salesman. Evidently bored with his later workaday life as an accountant, he turned to writing in 1933 and then produced some 60 works between 1934 and 1971. Genre considerations didn't seem to bother Clune much. Whether labelled autobiography or biography, exploration, history, novel, or travel, Clune's style consisted of piquant mock-journalistic narratives about larger-than-life characters and dramatic events. He exaggerated facts and passed off faked conversations as reportage. It is acknowledged that the influential and dogmatic Bulletin editor, P.R. Stephensen, had a significant hand in transforming Clune's material into written discourse.

Although his books were certainly popular best-sellers, Clune was also a regular broadcaster and had a journal titled Frank Clune's Adventure Magazine.

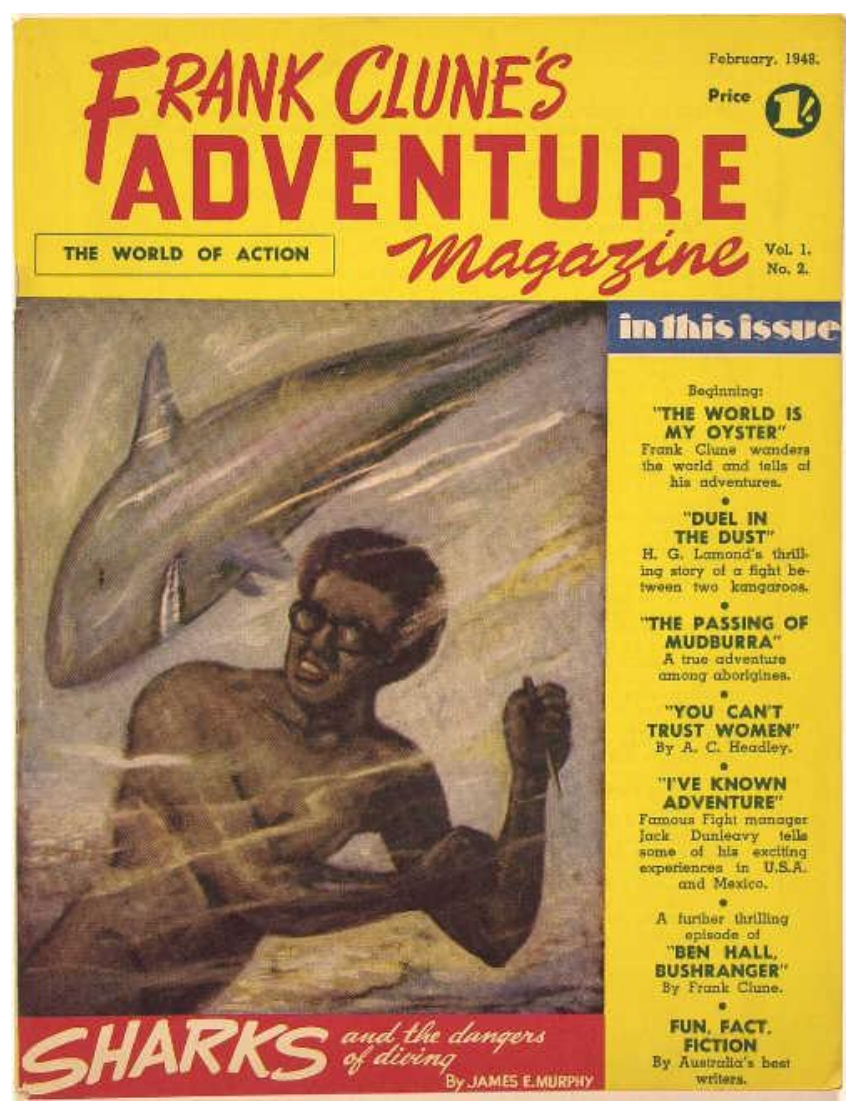



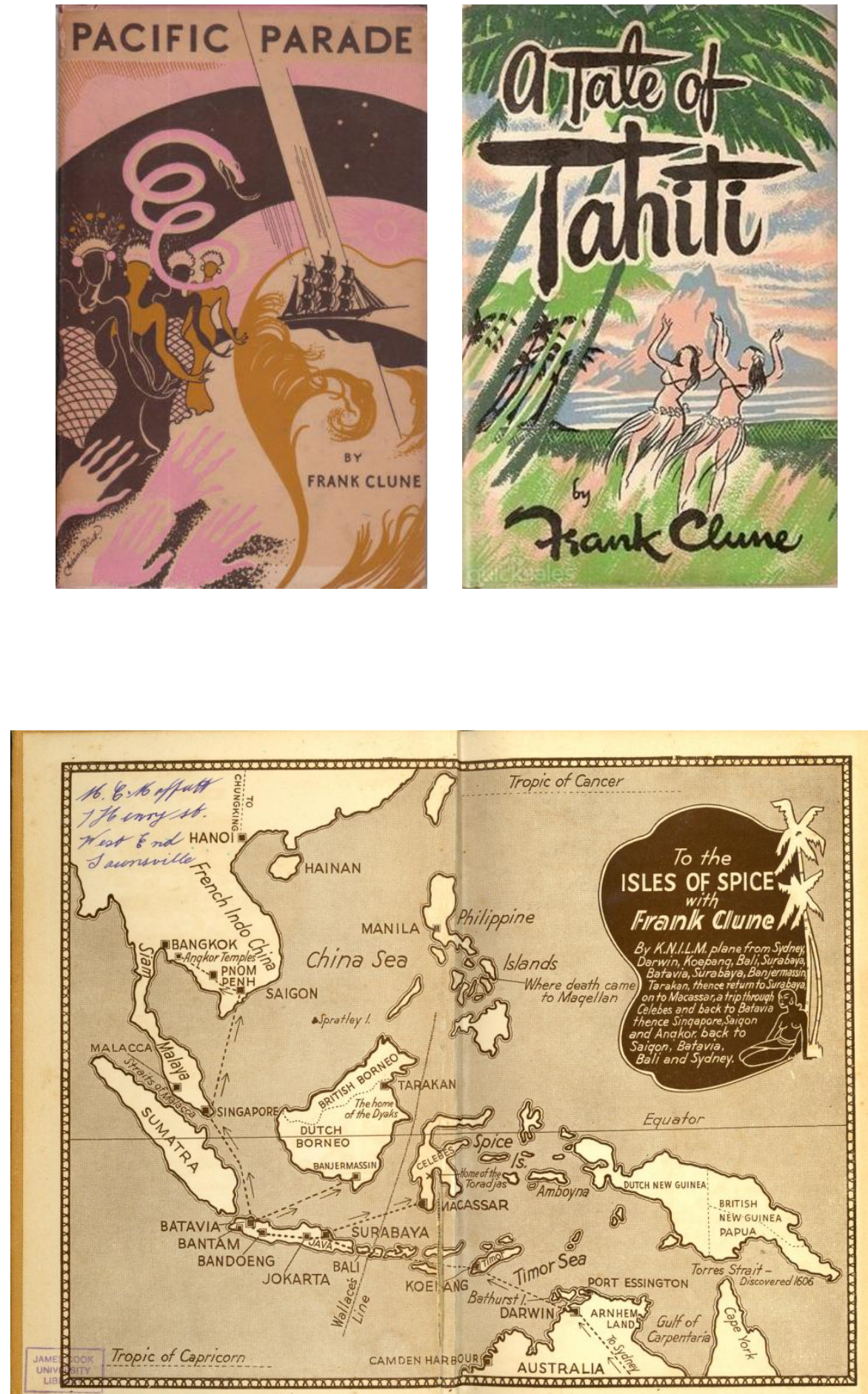

Inevitably he toured islands and wrote about them in works such as To the Isles of Spice (1940) Pacific Parade (1945) A Tale of Tahiti (1958). Apart from entertaining the reader with the usual mardi-gras of indigenous characters and customs, Clune frequently offers comments on the economic and political importance of islands. This is often expressed in metaphorical terms, especially in using jewels and pearls as metonyms of islands themselves. In Pacific Parade Clune refers to the "vast Dutch archipelago, which stretches like a necklace of jewelled isles, over a thousand miles from end to end, across the north of Australia" (45); he also notes that "the Spice Isles bask on in the tropic blaze, now, as ever, a pearl of great price, 
a reservoir of great wealth, a key-point in international politics—right at Australia's front door" (54).

But such serious socio-political concerns aren't pursued at length. Rather, Clune replays in his own voice the more traditional motifs of the island imaginary creating a crazy hybridity. Take this excerpt from Pacific Parade:

Java is the pearl in the Indonesian necklace of isles. It is the most fertile and most densely-populated place on earth. The Javanese people are small in stature, gentle and peace-loving and hard working. No wonder they have been conquered so often! They are so gentle they wouldn't hurt a fly. The soil of Java is volcanic, the rainfall abundant, the sun warm, the seas teeming with fish.... They have followed the religions of Hinduism, Buddhism and Islam in turn, and they are thus a highlycivilized people....Quite different from the Javanese and Balinese are the pagan people - the aborigines of Indonesia. They are nature worshippers, or animists, who believe that every living thing - trees and shrubs included-has a soul. These pagans, like the aborigines of Australia, are simple children of nature, survivors of the pretheological age. Their beliefs were formed in the days when the world was young. They have paradisal ideas - like Adam and Eve before the snake came and spoiled everything. (55-56)

Despite being ludicrously simplistic, patronising and racist, this passage nevertheless replays aspects of the island imaginary, especially the paradisal nature of island life, but paradoxically also the island as a projection of the binaries of savagery and civilization, paganism and religiosity.

Noting that "even in Java and Bali there are still survivals of the age-old pagan beliefs and customs" (56) by way of balance Clune throws in another cliché: "All the world knows about the tourist attractions of that glamorous little isle, where the women are all beautiful, barebreasted belles, and the men are all artist-craftsmen" (56). The rest of this chapter, "Monkey Dance" goes on to describe how Clune is put under the spell of witch-doctor and has a vision of a fierce encounter between monkeys and demons acted out by men and women. Clune reflects that "paganism had almost disappeared from the earth under the dual onslaught of religion and civilization, and I knew that I had been privileged to be present at one of the last remaining primitive orgies to be seen on this planet" (62).

Pacific Parade recycles material from earlier works, and indeed some of the substance above seems to have been lifted with little change from To the Isles of Spice. In the latter work the chapter cheekily titled "Bali-Belles, Cocks and Monkeys" surprises the reader when Clune says: "So much has been written about the feminine beauties of Bali ['Their longitude and latitude, / Have come to be a platitude.'] that the sports and pastimes of the mere males have been neglected. So I'll leave the gals to the poets, and tell you of an experience I had among Balinese men..." (309). A racy description of a cock-fight follows, with, it must be said, some acute appraisal of the various characters present. Clune concludes his description with: "I left the scene of carnage, and walked back to town, like many another punter; but consoled myself with the thought that I had had a fair run for my money" (311). Clune identifies as an ordinary Aussie punter, and so dispells the dissonance a reader might feel between disgust at cock-fighting and satisfaction of masculine sporting instinct. 
The uncontrolled heteroglossia of Clune's narratives is nowhere more foregrounded than in his transcription of comments written by VIP guests in the Complaints book at Jan's hotel on Bali. These texts provide a fascinating glimpse into the dissemination of Anglo-European discoursing on Asia, and the ambivalences within them. Having spent much of Pacific Parade and other works extolling the artistry of the Balinese people, Clune can't resist quoting a comment by Noel Coward, "written a few years ago, when he was here with Charlie Chaplin":

As I said this morning to Charlie

There is far too much music in Bali,

And although as a place it's entrancing,

There is also a thought too much dancing.

It appears that each Balinese native,

From the womb to the tomb is creative,

And although the results are quite clever,

There is too much artistic endeavour. (317)

Clune also reproduces a poem from "Sterham of Singapore" about the "Peaks of Bali" which set off a six-month train of responses:

Oh noble breasts of Bali,

Erect and proud you stand,

A bronzed and rhythmic setting,

To green and fertile land!

Ye beauteous breasts of Bali

To which thy children cling

And draw their living substance

From mother nature's spring!

Oh, laughing breasts of Bali,

That youth aspires to climb,

To stretch themselves upon thee,

In ecstasies divine!

Oh, welcome breasts of Bali

By age forever blest,

Where weary heads are pillowed,

In everlasting rest. (317)

Few subsequent guests accepted that Sterham's eyes were fixed on volcanic peaks. Among the responses was the following:

A rhyme-making Babbitt came out of the West,

Of beauteous Bali he saw but a breast,

He saw not the charm of the magical night,

Saw nothing at all when a breast was in sight.

He heard not the music of gamelan gongs

Or temple-maids chanting their mystical songs,

He saw not the temples of flame-trees aglow

Nor banners of palm-trees-his eyes were too low.

When Venus and Juno walked gracefully by

It was only their breasts that attracted his eye. 
The doctors will say, "He has breasts on the brain,"

When he has returned to his home town again.

If he goes to Heaven - he will not I fear-

God spare the angels his leacherous leer! (317)

When it comes to the stereotyping of the feminine in the island imaginary, the author of the above, "Mr George Caldwell, of Hollywood, Cal." certainly got it right. But Clune's obvious delight in reproducing these entries in the Complaints Book suggest a deeper than incidental correspondence between his work and the complaints: both play around persistent binaries and stereotypes in the island imaginary, and perpetuate a reification of the complexity and elusiveness of their subjects.

\section{Works Cited}

Banfield, E.J. Confessions of a Beachcomber. 1908. http://www.gutenberg.org/cache/epub/7177/pg7177.html

Banfield, E.J. My Tropic Isle. 1911. http://www.gutenberg.org/cache/epub/7177/pg7177.html

Bowen, James \& Bowen, Margarita. The Great Barrier Reef: History, Science, Heritage. Cambridge: CUP, 2002.

Clune, Frank. To the Isles of Spice. Sydney: Angus \& Robertson, 1940.

Clune, Frank. Pacific Parade. Melbourne: The Hawthorn Press, 1945.

Clune, Frank. A Tale of Tahiti. Sydney: Angus \& Robertson, 1958

Creed, Barbara and Hoorn Jeanette, eds. Body Trade: Captivity, Cannibalism and Colonialism in the Pacific. Annandale, N.S.W. : Pluto Press, 2001.

Devanny, Jean. By Tropic Sea and Jungle: Adventures in North Queensland Sydney: Angus and Robertson, 1944.

Dixon, Robert. "Captives and Inmates : Ion L. Idriess' Torres Strait Trilogy and the Aborigines' Protection Act". In Prosthetic Gods : Travel, Representation and Colonial Governance Robert Dixon, St Lucia : University of Queensland Press API Network , 2001.

“'Drums of Mer.': A Story of the Strait.” The Queenslander. Brisbane, Qld: 1866 - 1939. Thursday 14 December, 1933. P.44

Eley, Beverley. Ion Idriess. Sydney: Imprint, 1995.

Fuary, Maureen. "A novel approach to tradition: Torres Strait islanders and Ion Idriess." The Australian Journal of Anthropology 8.3 (1997): 247-258. 
Hurley, Frank. Pearls and Savages: Adventures in the Air, on Land and Sea in New Guinea. New York: Putnam's, 1924.

Idriess, Ion L. Drums of Mer. Sydney: Angus and Robertson, 1933.

Idriess, Ion L. Madman's Island. Second revised edition. Sydney: Angus and Robertson, 1938.

Idriess, Ion L. Headhunters of the Coral Sea. Sydney: Angus and Robertson, 1946.

Lindsay, Norman. The Cautious Amorist. London: T.Werner Laurie, 1934. Rpt. Sydney: Horwitz, 1969.

Lindsay, Norman. Age of Consent. New York: Farrar \& Rinehart, 1938. Rpt. Sydney: Ure Smith, 1962.

McGregorAlasdair. Frank Hurley: A Photographer's Life (Camberwell: Viking, 2004). 